\title{
REFLECTION AS A FACTOR OF THE ACTIVITY OF PROFESSIONAL COMPETENCE OF SOCIAL PEDAGOGUES
}

\author{
Valdonė Indrašienė \\ Mykolas Romeris university, Lithuania \\ Justinas Sadauskas \\ Mykolas Romeris university, Lithuania
}

\begin{abstract}
The study analyses the role of reflection in the context of professional improvement as one of the assumptions for profession competence of the social pedagogues. It is noted that reflection of professional experience is important in the preparation of the specialists providing social pedagogic assistance and in the improvement of their competence to act in both defined and undefined professional situations. Applying the qualitative research it has been established that in order to improve the provision of social pedagogic assistance it is important to continuously reflect on own professional activity. The research has established that reflection is one of the factors of the competence of specialists of the social pedagogics, since reflection of individual experience allows to consider actions, practicable methods, to foresee the results and the impact on the situation, on other people and on the person.
\end{abstract}

Keywords: reflection, professional improvement, risk families social work.

\section{Introduction}

Social economic changes influenced many areas of society life, at the same time influencing the human being and the environment. The belief in the human ability to change the world as the value has been noted by A.P. Wilson (1997, 749), the power is concentrated in the human ability to understand the reality, to generate knowledge of the reality through action and reflection, to create own identity and become more human. It should be noted that the professional competence of social pedagogic assistance is determined by three essential dimensions of professional work - to think, to perform and to act integrally (Shulman, 2005), i.e., to reflect own professional experience (Bubnys and Gudonis, 2009). In the practice of social pedagogic assistance reflection is emphasized, since a reflective professional integrates knowledge, values, abilities into his/her work and learns from the experience at the same time (Toros, ir Medar, 2015). Ability to reflect helps to learn from own experience (Motiečienè ir Naujanienè, 2011), to analyse objects, processes remote from a known subject, to analyse own activity as a subject of the experience (Mažeikis, 2007). 
The importance of the reflexion is especially noted speaking about the professional training of the future specialists of social pedagogic assistance (Raudeliūnaite, 2010 Laverty, 2012). Reflexion is associated with the professionalism of social work (Fook ir Askeland, 2009, Švedaite, 2012; Bubnys, 2014), with the abilities of a social pedagogue to make decisions (Jonušaitè, 2009), with supervision (Abromaitienè, 2013).

Reflexion is required for oneself rather than in respect of the others, i.e., every idea that is newly reflected encourages correction of own ideas, of the activity, of the attitudes and of the own relationship with the object. The way of recognition (reflexion) should start from recognition of oneself; only the person realising oneself may better know the others, may get integrated into the society, into the community, help others to improve and to find their ways to the society. According to O. Tijūnelienè and V. Kavaliauskienè (2009), reflexion is a guaranty of constructive professional improvement.

Goal of the study: to analyse the most important aspects of practical experience reflection of the specialists of social pedagogic assistance, as of one factor of professional competence development.

\section{Objectives:}

- To analyse the meaning of activity reflexion in the context of professional competence.

- To disclose the experience of social pedagogic assistance applying the reflexion method as the factor of training of professional competence in work with the families at risk.

Research methods: the qualitative method was used (Bitinas et al., 2008; Merriam, 2009). For the data collection a semi-structured interview was used, since more explicit information can be obtained, the data may be specified and enriched with additional questions to the respondent, the research gets deeper and broader (Tidikis, 2003).

5 providers of social pedagogic assistance from $X$ region, having the minimum 10 years social or pedagogic assistance to children in families at risk participated in the research.

The data of the research were analysed applying the content analysis method, the data were grouped and re-grouped, a comparison of the data and of the descriptive categories, and of the subcategories was performed. The final result of the research is the descriptive categories which are applied on the deep analysis of the primary data.

The feasibility of the research was secured by careful transcriptions of the interviews with the informants - re-writing the unique speeches of the informants, registering the pauses and emotions. In the analysis of the data the authentic language of the informants is presented. 
Limitation of the research is that only a small part of the specialists that provide social pedagogic assistance to children in families at social risk was surveyed. Therefore it can be asserted that personal experiences and subjective assessments of the specialists that provide social pedagogic assistance to children in families at risk is disclosed.

The following principles were followed in the process of data collection: free choice, confidentiality and anonymity. Explicit information about the purposes of the research, about where and how the material obtained during interviews will be used was provided; the participants of the research were informed about the possibility to withdraw from the research and to refuse any time to answer the questions that are not acceptable for them.

\section{Reflection as a condition for professional activity improvement}

A professional specialist must be a researcher of own activity, at the same time of experience, continuously acting, considering own ideas and theories that he/she follows, aiming at the implementation of the results of own activity (Bubnys, Krušaitè, 2008). reflection provides conditions to aim for changes and to search for alternative ways of social activity that would help to overcome new challenges, to solve the problems of social assistance in the modern world (Vaicekauskienè, Čiužas, 2013). Therefore, according to Raudeliūnaite (2010), new knowledge, understanding, new sense and perception could be the result of reflection. A professional specialist must become a researcher of own activity and at the same time of the experience: that is a person continuously acting, considering own ideas and the theories in use (Bubnys, 2009).

According to R. Bubnys and V. Gudonis (2009), the essential process of a professional development is orientated towards the ability of the person to learn continuously through the ability to reflect, getting deeper into the experience analysis, its improvement and reasoning, updating and re-assessing the knowledge, better knowing and controlling oneself, diagnosing personal mistakes, forming the ability of efficient analysis. Reflection is directly related to the motivation of a professional for conscious activity and it's modelling, correction, it indirectly determines own empowering for continuous improvement accepting responsibility for own actions and decisions.

Reflection in professional activity, the expression of the culture of reflection bring distinct colours into the activity of the specialists of the social pedagogic assistance (Kavaliauskienè, 2010):

- Reflection, the culture of reflection, ,participate“ in the updating of the personality of a professional - in the cognitive field, in the emotional field (realising the factual possibilities of own influence on the activity objects). 
- Reflection highlights the relationship of the professional with oneself and makes it transparent.

Reflection opens for a specialists of social pedagogic assistance opportunities to apply knowledge, values and skills in a creative manner, allows to open oneself for new phenomena, information, to apply other than the standard ways of action and interventions. R. Bubnys and L. Krušaite (2008) note that reflecting a professional gains "invisible" knowledge and skills, therefore he or she may chose appropriate strategies, make adequate decisions not only in the professional activity, but in different life situations as well. According to the authors, by reflecting we know ourselves, we look at the same problem from different angles, we consider not just the positive experience, but the negative one as well, realising our weak and strong sides. According to R. Bubnys and V. Gudonis (2009), reflection comes from professional experience therefore it includes reflective thinking forming a situation when the personal system of attitudes, values and views is relied on, leaving an open opportunity for its reformation. The experience is reconstructed using reflection which might be explained as a process, when attention is paid to the experience and its content, leading to conscious knowledge of theories of personal activities, their development, creation of new knowledge and checking of it in real practice (Stanikūnienè, 2007), encouraging the search for additional information which could help to understand the essence of the problem (Gapšytė, Snieškienè 2011).

According to the researchers, reflection is one of the important features that determines professional fitness and adaptability to the profession (Kepalaite, 2008) and influences qualitative professional development of the personality and professional identity (Raudeliūnaite 2010). So it is natural that the development of reflection competence should become one of the most important goals in preparation of specialists that work directly with people, since it is necessary to reflect oneself in order to improve the relationship at work (Jansen, 2010). According to D. Gamble and M. Weil (2005), the theoretical and scientific knowledge of a practitioner enriches his/her reflection, and at the same time reflection allows to personalise the theoretical knowledge, to adjust it for solutions of specific situations, and opens a new horizon of activity, discloses new meanings, potentials of solutions. Reflection actualise the relationship between the theory and the practice, the inter-relationship of the personal and the professional experience which is very important in the process of professional improvement of a social worker (Dirgèliené, 2008).

According to V. Lukošuniniené, (2011) the results of the reflection of the past and of the present have direct influence on improvement of adults in future, on future goals setting, on improvement of the skills to learn. Ability to consider the experience should be applicable in the professional activity of a pedagogue 
as a possibility for improvement of own activity and of further strategies (Teresevičienè, Gedvilienè, 2001).

According to I. Dirgelienè and N. Večkienè, (2009), reflection has an important role in the mechanism of stress overcoming, or self-control, since reflection includes understanding and assessment of oneself and of the other person, the comparison of own opinion with the opinions of other people and of the entire society. According to the authors, the specialists that face some difficulties, doubts, complexity of a professional situation or a lack of knowledge, should have a possibility to discuss all this with colleagues and specialists.

Thus, reflection in the process of social pedagogics assistance has a special meaning since it allows discovering and knowing one's feelings, the motives of behaviour, lets to analyse the achievements and drawbacks of own activity or learning. Reflection is one of the strategies of improvement, a valuable skill to support efficient professional practice in future.

\section{Experience of the specialists of social pedagogics assistance applying the method of reflection as a factor of professional competence development in work with children in families at social risk}

Analysing the experiences of the specialists of social pedagogic assistance applying the method of reflection the subject of "Context of reflection of professional activities" was distinguished. The subject is specified with two categories: the need for activity reflection, and the time and the place allocated for that. It was disclosed that specialists reflect about their professional activities in home environment, at work or anywhere in critical cases: when facing difficulties in provision of assistance, having experienced comments from a manager or a colleague, getting negative reactions from clients (Fig. 1).

During the research it appeared that the specialists of social pedagogic assistance reflect on their activity in critical cases - when they are not satisfied with their professional activity or when others express such dissatisfaction. In such cases the activity is reflected here and now - in the work environment:

<...> I got furious with the director and with myself... Don't know with whom more ... (laughs) and left for smoking, so I could be alone and think about my work" (P3)

"In such cases [when there is a need for reflection] there is no place where you could close the door of the office and stay all alone and think the problem over, so that nobody disturbs you. But we have no place like that, so I pretend working with papers and think and consider, analyse what a colleague said, why did she say so" (P1). 


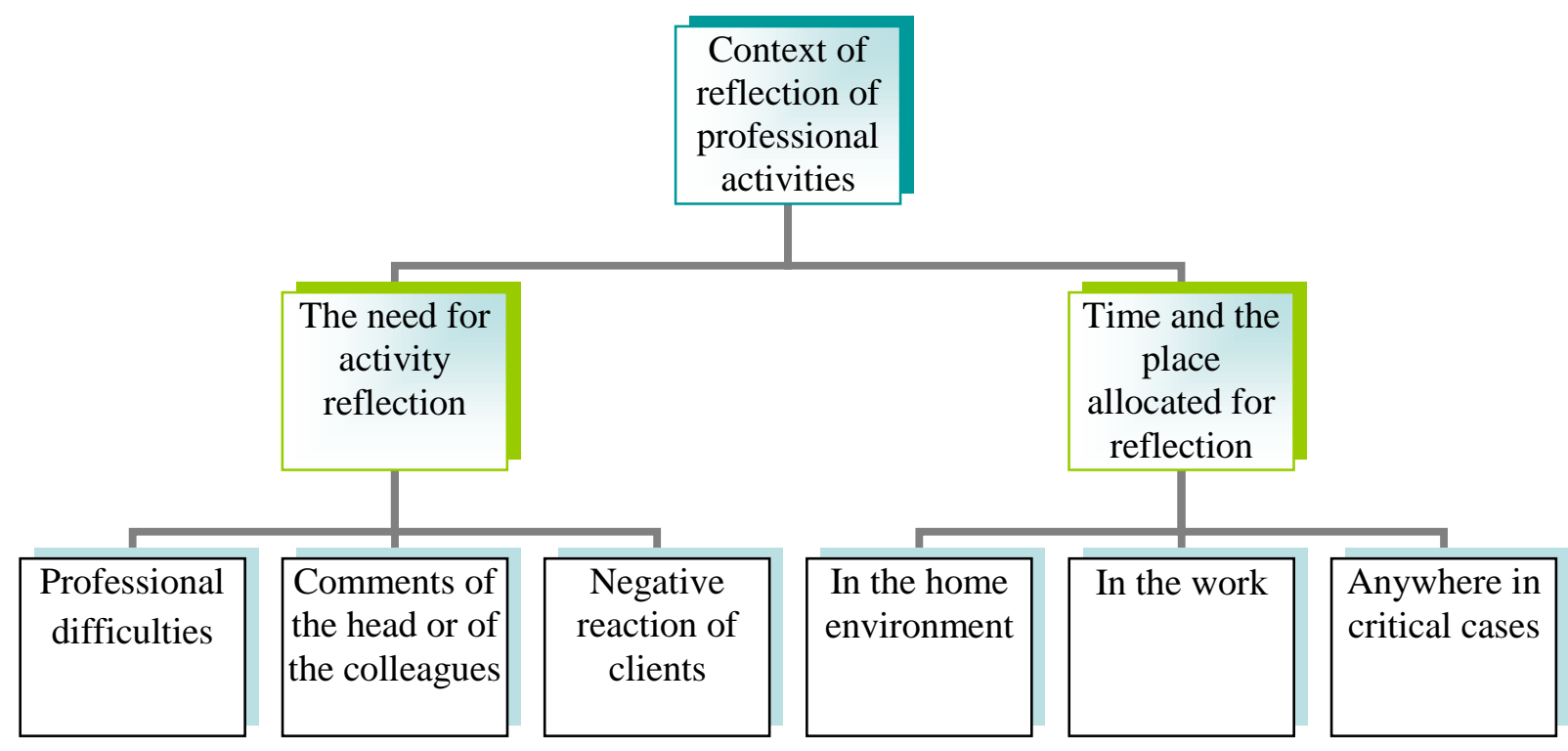

Figure 1 The need and the time allocated for professional activity reflection as expressed by the specialists of social pedagogic assistance

Anyhow, the activity is the most often reflected in the home environment, doing various household works: cooking, cleaning or relaxing:

$<. . .>$ when I got back home I still long thought about my work, about the situation. Whatever I did, I still kept thinking what was to be done next, what to do with the child ... I could not fall asleep ... very often I thought about him, he was with me, like a shadow <..> ... (P5).

$\langle\ldots\rangle$ at home I analyse the situations of the clients, in other words - I bring work home, there is no line between the work and personal life, I get emphasized. Work gets mixed with free time. Sometimes I start analysing a situation against my will ( $P 2)$.

When facing critical situations in professional activity, the informants note that they often reflect the situation continuously and that the place is of no importance: not just at work or at home, but even walking in a street "I keep going and keep thinking, analyse the situation which I cannot settle. Even forgot to go shopping "(P5), in a bathroom which is "the best place for reflection of my work, since nobody disturbs there" (P1) or in bed "before sleep I start thinking over the situations that occurred at work" (P2).

The informants see the need for reflection when professional difficulties occur in provision of social pedagogic assistance. When after work, at home "the head bursts to pieces from not knowing what to do" $(\mathrm{P} 1)$ and even a regular promise "you close the door of your home and...stop thinking about the problem" (P3) does not help, the informants consider the situations that makes them worried: 
"<...> I can distinguish one family where they had 4 boys, the man and the woman abused alcohol <....> We found some relatives of the woman, after our long arguing into the woman decided to go for treatment, she was paid a onetime allowance for treatment against alcohol. After a week I visited the family and the mother was totally drunk. I thought the issue over and over all evening. " (P1)

Comments of the head or of the colleagues also cause reflection of professional activities as well as dissatisfaction with decisions made. Often a specialist of social pedagogic assistance feels lonely facing the clients and their problems, responsible for provision, planning and organization of assistance for particular client. Therefore it is important for him/her to get support and assistance in difficult situations, feeling unpleasant condition because of circumstances at work, from both the managers and the colleagues. And when he/she does not feel such support, and even more- is criticized - that, according to the informants, encourages them to reflect on their activity, so that in future they could avoid unnecessary tension or reproaches:

"<...> at home, after one such meeting when the director noted again that the social pedagogue was incapable to solve the problems of children in families at social risk, so that different strategies had to be applied...I kept reflecting all day long - what did I do wrong?...." (P4).

"<...> and then you think, [a colleague] said that I fail to manage with this family, that I work wrongly, so I start thinking at once - but how? How shall I work, when it seems that I tried everything..... <...> I can hear the words of the colleague even at home and keep thinking about the family and the children..." (P2).

Negative reaction of clients, their dissatisfaction with the decisions of the specialist, the regular attitude towards the specialists also encourage the reflection of the activity - "as if why do I work, anyway, I cannot do anything...I am worth nothing and what do I do in this institution" (P2). The results of the research correspond to the results of R. Lazutka research - that the threat felt from the client is a frequent escort of a social worker; therefore it is very important for social workers to have enough knowledge and skills about behaviour in such situations (Lazutka and al, 2008, p. 80). It has been disclosed that reflection of own activity is encouraged by expressed aggression of clients when " $\langle\ldots>$ they call you various names, curse on you" and by disapproval of the decisions of the specialist: "Recently an awful thing happened, one family with children suffered a great loss - their only patroness died; the behaviour of the children changed, they suffer the loss, have more conflicts with teachers. They argue with me that they are not going to do this and that...As if I am inventing unnecessary things for them. That works emotionally, so I keep 
thinking how to find an approach to the children, what to offer them, in what way to say and so on ". (P5);

Thus, the need for reflection is associated with dissatisfaction with one's work that the specialists feels themselves or that the manager or other specialists and clients express. Though the research (Bubnys ir Petrošiūtè, 2008) shows that social pedagogues and workers tend to assess own relationships with managers and colleagues more positively, and the work relationships with clients more negatively, the informants named the comments and dissatisfaction with their work of the managers and colleagues as one of critical situations which encourage the reflection of one's work.

It should be noted that the experience expressed by the informants leads to thinking that long-lasting dissatisfaction with own professional decisions, poor relationship with colleagues and lack of support from managers prompt the workers to believe that their skills do not correspond to the requirements of the work; lack of self-confidence, distrust in work methods occur and all this provides conditions for formation of the "burn out" syndrome (Renzi and al., 2012; Newton-Scanlan and Still, 2013, Zafar and al., 2014). Therefore it is important that the specialists of social pedagogic assistance learn to control negative emotions in critical situations, are able to find the balance between possibilities and wishes, to set priorities and etc. (Marc and Osvat, 2013). Aiming at successful professional activity it is required not just reflect on critical situations, own possibilities, but also to design new plans of activity (Jovaiša, 2009), not just consider own activity, decisions made, but also foresee further steps of activity:

“... I must say that this continuous dissatisfaction with one's work, continuous thinking what to do to make things better brought me to the answer and the further way...Since I felt the lack of knowledge I started to more actively learn about the specifics of my work, about conflict management and other issues which are focussed on the persons from risk families (P3).

"<...> I decided to have as many contacts as possible, to cooperate, and to share experiences and difficulties with colleagues, to look for advice, to ask what they do in one or another situation. It really helps to get discharged. The support of the colleagues gave me the feeling that I was not alone and that the problems arising at work might be settled" (P5).

Hence, problem situations might be solved as a result of constructive reflection, innovations in own activity are being searched for relying on the experience of the colleagues (Bubnys ir Krušaite, 2008), the experience is shared with colleagues and co-workers (Bičkute ir Liobikienè, 2011).

The analysis of the experience of the informants disclosed one more issue "Impact of activity reflection on professional improvement" (Fig. 2). 
According to the specialists of social pedagogic assistance, the activity reflections encourage learning from own experience, sharing experience with others and engagement in self-improvement.

Consideration of own experience, the analysis of the situation and assessment encourage using the available experience, learning from practical situations:

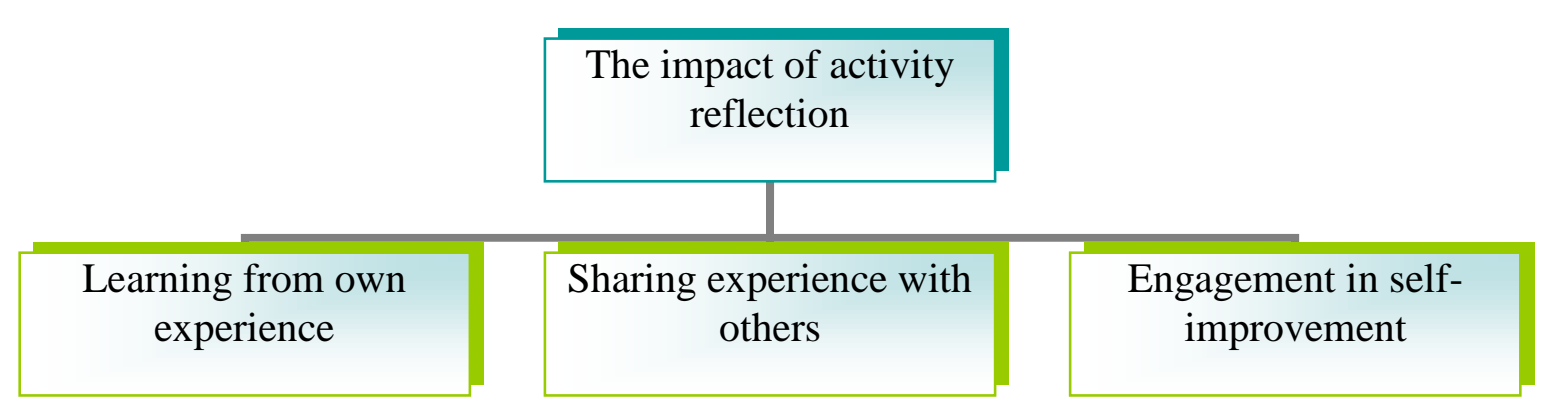

Figure 2 Impact of reflection applied by specialists of social pedagogic assistance on professional improvement

"I think that I learned to work with those persons from practical situations... You think it over, consider and learn from your own mistakes, from successful solutions of situations... I see that, for example, that action in respect of the child was good, so maybe to do the same now again, but maybe to make an agreement with the parents in addition." (P 4)

"Of course you go on and on with reflection, and big practical experience occurs... You learn from practical situations that you face and use the experience in other similar situation." (P1).

Activity reflection helps the specialists not just to look for problem solutions learning from own experience, but also to look for assistance in professional literature:

"After those conflict situations with the parents of the girl I read plenty of literature, about conflict management, about work with families at risk. And it got brighter, it helped" (P3), and to initiate collegial learning:

"<..> So I said to myself - how long you have talk to yourself when we can reflect on our decisions and actions in the Commission [Child's Welfare Commission]. So I suggested to sit all together once a month and share own reflections on what to do, what are the problems, how to settle them and what to do to make things better" (P4).

Thus, involvement of other team members into activity reflection encourages sharing of experience, efficient cooperation takes place, all team members participate solving problems (Čegytès ir Ališauskienė, 2009).

The informants recognised that, when reflecting on own activity, they realised that that they often faced situations when they did not know how to 
solve one or another problem, or how to behave in a specific situation, therefore one of the possibilities to improve in professional activity is to take over the experience of colleagues:

"I learned and am still learning communicating with colleagues.... <..> I share my experiences with a reliable colleague. He does the same" (P2).

It has been established that for the specialists that work with people and for them, reflective practice is a must since it opens opportunities to apply knowledge, values and skills in a creative manner, to open new phenomena, information, to apply non-standard ways of action and intervention" (Kavaliauskiene, 2010, 170). So, activity reflection also encouraged the specialists of social pedagogic assistance for a new way of action - self improvement:

"<..> I tried to change my thinking which was orientated to the fact that my assistance and the final results did not depend just on me; the most actually depends on the client, his/her motivation and involvement." (P2),

"<..> I started to get interested in stress fighting, looked for various exercises of relaxation that I could apply at once, in my work place, after some unpleasant situations (P5).

Self-improvement as a conscious and guided process of self-recognition, controlled by the person himself/herself is associated not just with consciousness, independence and self-expression of the personality, but also with a life-lasting development process of the human being (Vaivada, ir kt., 2012). The need of the person for self-development occurs only when the person is not satisfied with the existing situation and seeks for changes (Indrašiene ir Kolbergyte, 2012). Therefore a specified self-improvement or an attitude towards particular actions of self-improvement that helps to perform professional activity successfully opens ways for professional improvement for the specialists.

That means that the activity reflection encourages the specialists of social pedagogic assistance to assess their professional activity, particular actions, and their efficiency diversely and critically, and better understand the reasons of the arising difficulties. And that means that reflection helps to make the optimal decisions, to adjust own activity, to improve its results and to consider the criteria of successful activity.

\section{Findings}

Specialists of social pedagogic assistance reflect on professional activity when they face critical situations which arise with difficulties in provision of assistance or with dissatisfaction of the others with a decision made. Reflection 
takes place immediately after the activity (work environment) or after some time (home and other environment).

Long-lasting dissatisfaction with own professional decisions, lack of support from managers and colleagues create preconditions for occurrence of the "burn out" syndrome, therefore it is important that the specialists of social pedagogic assistance learn to reflect constructively on professional activity.

Constructive reflection of activity encourages to learn from own experience, sharing it with the others and to engage in self-improvement; it empowers the specialists of social pedagogic assistance to correct their activity, to improve its results and to consider the criteria of successful activity.

\section{References}

Abromaitienè, L. (2013). Supervizija kaip pedagogu profesinio tobulèjimo galimybè. Pedagogika, 112, 34-40.

Bičkute, A., \& Liobikienė, T. N. (2011). Socialinio darbuotojo ir agresyviai besielgiančio kliento sąveika socialiniame darbe. Socialinis darbas. Patirtis ir metodai, 7 (1), 89-111.

Bitinas, B., Rupšienè, L., \& Žydžiūnaitè, V. (2008). Kokybiniu tyrimu metodologija. II dalis. Klaipèda: Socialinių mokslų kolegija.

Bubnys, R. (2014). Reflektavimo kompetencijos struktūra socialinio darbo studentams atliekant praktikas. Socialine teorija, empirija, politika ir praktika, 9, 50-63.

Bubnys, R. (2009). Reflektyvus mokymasis kaip edukacinis fenomenas ugdant specialiuosius pedagogus aukštojoje mokykloje. Šiauliai :Šiaulių universitetas.

Bubnys, R., \& Gudonis, V. (2009). Būsimų specialiujų pedagogų asmeninès patirties reflektavimas ir integravimas praktinèse studijose aukštojoje mokykloje. Specialusis ugdymas, 2 (21), 83-9.

Bubnys, R, \& Krušaitè, L.(2008). Socialinių pedagogu ir socialinių darbuotojų reflektyvavimo ypatumai profesinèje veikloje. Jaunuju mokslininku darbai, 2 (18), 6570.

Bubnys, R., \& Petrošiūtè, D. (2008). Socialiniu pedagogu ir socialinių darbuotoju gyvenimo kokybès vertinimas: profesinis aspektas. Jaunuju mokslininku darbai, 4 (20), 103-108.

Čegytė, A., \& Ališauskienè, F. (2009). Specialistų komandos bendroji pasidalyta kompetencija tenkinant vaiku specialiuosius poreikius: koncepto analizè. Jaunuju mokslininku darbai, 1 (22), 33-45.

Dirgèlienè, I. (2008). Teorijos ir praktikos ryšio plètotè socialinio darbuotojo profesinejje veikloje. Acta paedagogica Vilnensia, 28, 90-101.

Dirgèlienè, I., \& Večkienè, N. P. (2009). Streso rizika ir paramos lūkesčiai: socialinių darbuotojų profesinès patirties analizè. Tiltai, 1 (46), 143-162.

Fook, J., \& Askeland, D. A. (2009). Critical reflection in social work. European Journal of Social Work, 12 (3), 287-292.

Gamble, D. N., \& Weil, M. (2005). In The Handbook of Community Practice. London: SAGE Publications. P. 153-168.

Gapšytė, R., \& Snieškienè, D. (2011). Socialinio darbuotojo etinė kompetencija ir jos vystymo praktikoje galimybès. Socialinis darbas. Patirtis ir metodai, 7, 113-129,

Indrašienè, V., \& Kolbergytè, A. (2012). Sąmoningumo ugdymo akcentai: požiūriai ir interpretacijos. Socialinis darbas, 11 (2), 421-432. 
Jonušaitè, S. (2009). An Analysis of Implementation of School Social Pedagogue s Making of. Professional Decisions as a Prerequisite for Development of Professional Competences Socialiniai tyrimai, 1 (15), 18-27.

Jovaiša, L. (2009). Gyvenimo sèkmès ugdymas. Vilnius - Agora.

Kavaliauskienè, V. (2010). Refleksijos kultūra - socialinio darbuotojo profesinès veiklos raiškos aspektas. Acta paedagogica Vilnensia, 25, 159-171.

Kepalaite, A. (2008). Socialiniu pedagogu subjektyvaus patyrimo apie konfliktines situacijas analizè. Specialusis ugdymas, 2 (19), 59-66.

Laverty, J. (2012). Reflective learning within clinical physiology: The student's perspective on the usefulness of reflection as a learning tool. Reflective Practice: International and Multidisciplinary Perspectives, 13 (1), 131-147.

Lazutka, R., Skučienè, D., Žalimienè, L., Vareikytè, A., \& Kazakevičiūtè, J. (2008). Socialinių darbuotojų profesinès rizikos veiksniai. Socialinis darbas, 7 (3), 74-86.

Lukošūnienè, V. (2011). Refleksija kaip integrali mokymosi mokytis kompetencijos dalis. Pedagogika, 101, 43-49.

Marc, C., \& Osvat, C. (2013). Stress and burnout among social workers. 12 (3), 121-130.

Mažeikis, G. (2007). Kompetenciju ugdymo sistema taikant kooperuotu studiju metoda. Šiauliai: Šiaulių universiteto leidykla.

Merriam, S. B. (2009). Qualitative research: A guide to design and implementation. San Francisco, CA: Jossey Bass.

Motiečienè, R., \&, Naujanienè, R. (2011). Socialinių paslaugų sistemos dalyvių, socialinių darbuotojų ir klientu, patirties kritinè refleksija. Socialinis darbas: patirtis ir metodai, 7 , 9-29.

Newton-Scanlan, J., \& Still, M. (2013). Job satisfaction, burnout and turnover intention in occupational therapists working in mental health. Australian occupational therapy journal, 60 (5), 310-318. doi: 10.1111/1440-1630.12067.

Raudeliūnaitè, R. (2010). Socialinio darbo studentų patirtis studijų praktikoje: rašytinių refleksiju analizè. Socialinis darbas, 9 (2), 48-55.

Renzi, Ch., Pietro, C. D., \& Tabolli, S. (2012). Psychiatric morbidity and emotional exhaustion among hospital physicians and nurses: association with perceived job-related factors. Archives of environmental \& occupational health, 6 (2), 117-123. doi: 10.1080/19338244.2011.578682.

Shulman, L. (2005). Signature pedagogies in the professions. Daedalus, 134 (3), 52-59.

Stanikūnienè, B. (2007). Aukštosios mokyklos dèstytojo edukacinès kompetencijos ir mokymosi aplinku santykis. Kaunas: Kauno technologijos universitetas.

Švedaitè-Sakalauskè, B. (2012). Kodèl refleksija? Apie socialini darbą kaip refleksyvų profesionaluma. Socialine teorija, empirija, politika ir praktika, 6, 23-32.

Teresevičienè, M., \& Gedvilienè, G. (2001). Mokytojo profesinio tobulèjimo galimybès: patirtis ir refleksija. Pedagogika. 51. 133-145.

Tidikis, R. (2003). Socialiniu mokslu tyrimu metodologija. Vilnius: Lietuvos teisès universitetas.

Tijūnelienè, O., \& Kavaliauskienè, V. (2009). Juozo Vaitkevičiaus kvietimas mokytojui pažinti save. Acta Pedagogica Vilensia, 22, 174-183.

Toros, K., \& Medar, M. (2015). Social Work Students' Thoughts on Self -Reflection: A Qualitative Study Based on Reflective Journaling. International Journal of Humanities and Social Science, 5 (3), 89-96.

Vaicekauskienè, V., \& Čiužas, R. (2013). Reflektyviojo modelio taikymo teorinès prielaidos socialinių darbuotojų rengime. Socialinis ugdymas, 2 (34), 139-149. 
Proceedings of the International Scientific Conference. Volume I, May $27^{\text {th }}-28^{\text {th }}, 2016.102-114$

Vaivada, S., Blinstrubas, A., \& Mockevičienė, D. (2012). Skirtingų lygių asmeninių žinių fenomenai asmenybès dimensijose: asmenybès saviugdos kontekstas. Studijos šiuolaikineje visuomenèje, 3 (1), 255-266. Šiauliai: Šiaurès Lietuvos kolegija.

Wilson, A. P. Building Social Capital: A Lerning Agenda for the Twenty - first Century. Urban Studies. 1997, 34 (5-6): 745-760.

Zafar, A., Zahra, N., \& Zia, Y.A. (2014). Antecedents of job burnout among bank employes. Humanities and social sciences, 21 (2),13-24. 